\title{
A proposed origin for fossilized Pennsylvanian plant cuticles by pyrite oxidation (Sydney Coalfield, Nova Scotia, Canada)
}

\author{
ERWIN L. ZODROW \& MARIA MASTALERZ
}

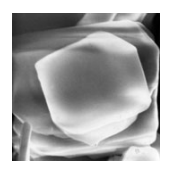

\begin{abstract}
Fossilized cuticles, though rare in the roof rocks of coal seam in the younger part of the Pennsylvanian Sydney Coalfield, Nova Scotia, represent nearly all of the major plant groups. Selected for investigation, by methods of Fourier transform infrared spectroscopy (FTIR) and elemental analysis, are fossilized cuticles (FCs) and cuticles extracted from compressions by Schulze's process (CCs) of Alethopteris ambigua. These investigations are supplemented by FTIR analysis of FCs and CCs of Cordaites principalis, and a cuticle-fossilized medullosalean(?) axis. The purpose of this study is threefold: (1) to try to determine biochemical discriminators between FCs and CCs of the same species using semi-quantitative FTIR techniques; (2) to assess the effects chemical treatments have, particularly Schulze's process, on functional groups; and most importantly (3) to study the primary origin of FCs. Results are equivocal in respect to (1); (2) after Schulze's treatment aliphatic moieties tend to be reduced relative to oxygenated groups, and some aliphatic chains may be shortened; and (3) a primary chemical model is proposed. The model is based on a variety of geological observations, including stratal distribution, clay and pyrite mineralogies associated with FCs and compressions, and regional geological structure. The model presupposes compression-cuticle fossilization under anoxic conditions for late authigenic deposition of sub-micron-sized pyrite on the compressions. Rock joints subsequently provided conduits for oxygen-enriched ground-water circulation to initiate in situ pyritic oxidation that produced sulfuric acid for macerating compressions, with resultant loss of vitrinite, but with preservation of cuticles as FCs. The timing of the process remains undetermined, though it is assumed to be late to post-diagenetic. Although FCs represent a pathway of organic matter transformation (pomd) distinct from other plant-fossilization processes, global applicability of the chemical models remains to be tested. CCs and FCs are inferred endpoints on a spectrum of pomd which complicates assessing origin of in-between transformations (partially macerated cuticles). FCs index highly acidic levels that existed locally in the roof rocks. $\bullet$ Key words: Carboniferous, fossilized cuticles, natural maceration, pyrite oxidation, FTIR.
\end{abstract}

ZODROw, E. \& MASTALERZ, M. 2009. A proposed origin for fossilized Pennsylvanian plant cuticles by pyrite oxidation (Sydney Coalfield, Nova Scotia, Canada). Bulletin of Geosciences 84(2), 227-240 (15 figures, 4 tables). Czech Geological Survey, Prague. ISSN 1214-1119. Manuscript received July 23, 2008; accepted in revised form February 3, 2009; published online April 1, 2009; issued June 30, 2009.

Erwin Zodrow, Department of Geology, Cape Breton University, Sydney, Nova Scotia, B1P 6L2 Canada; Erwin_Zodrow@cbu.ca・Maria Mastalerz, Indiana Geological Survey, Indiana University, 611 N. Walnut Grove, Bloomington, IN 47405-2208, USA; mmastale@indiana.edu

Fossilized-plant cuticles (referred to as FCs) have been known to exists for almost 250 years in the sedimentary basins of Devonian to Miocene ages. In the Pennsylvanian Sydney Coalfield (Fig. 1), they occur as intact cuticlefossilized pinnate structures as large as $30 \mathrm{~cm}$, particularly of medullosalean and marattialean groups, or as detached leaves. These plant-cuticle structures are "ready made" for light and electronic microscopic observations, and surpass in size even the larger pteridospermous [leaf] cuticles obtained by Krings \& Kerp's (1997) maceration process, not to mention the ferny cuticles from which otherwise only millimeter-size cuticles could be extracted (Barthel 1962, summary: Pšenička 2005, Zodrow \& Mastalerz 2002).
The primary origin of FCs remains unknown, and therefore pathways of organic matter transformation as related to phytochemotaxonomic investigation remain unexplored. The circumstance and inconsistent nomenclature for FCs probably contributed to the infrequent references to FCs in the literature (e.g., Roselt 1956, p. 84; Mägdefrau 1956, Schopf 1975, Taylor \& Taylor 1993). FCs were probably first described by Göppert (1841, pl. IV), while Unger (1852) published morphological studies on epidermal structures. Schulze (1855) experimented with brown coal and established a chemical protocol known today as Schulze's [maceration] process which is used for extracting cuticles from [coalified] compressions (herein referred 


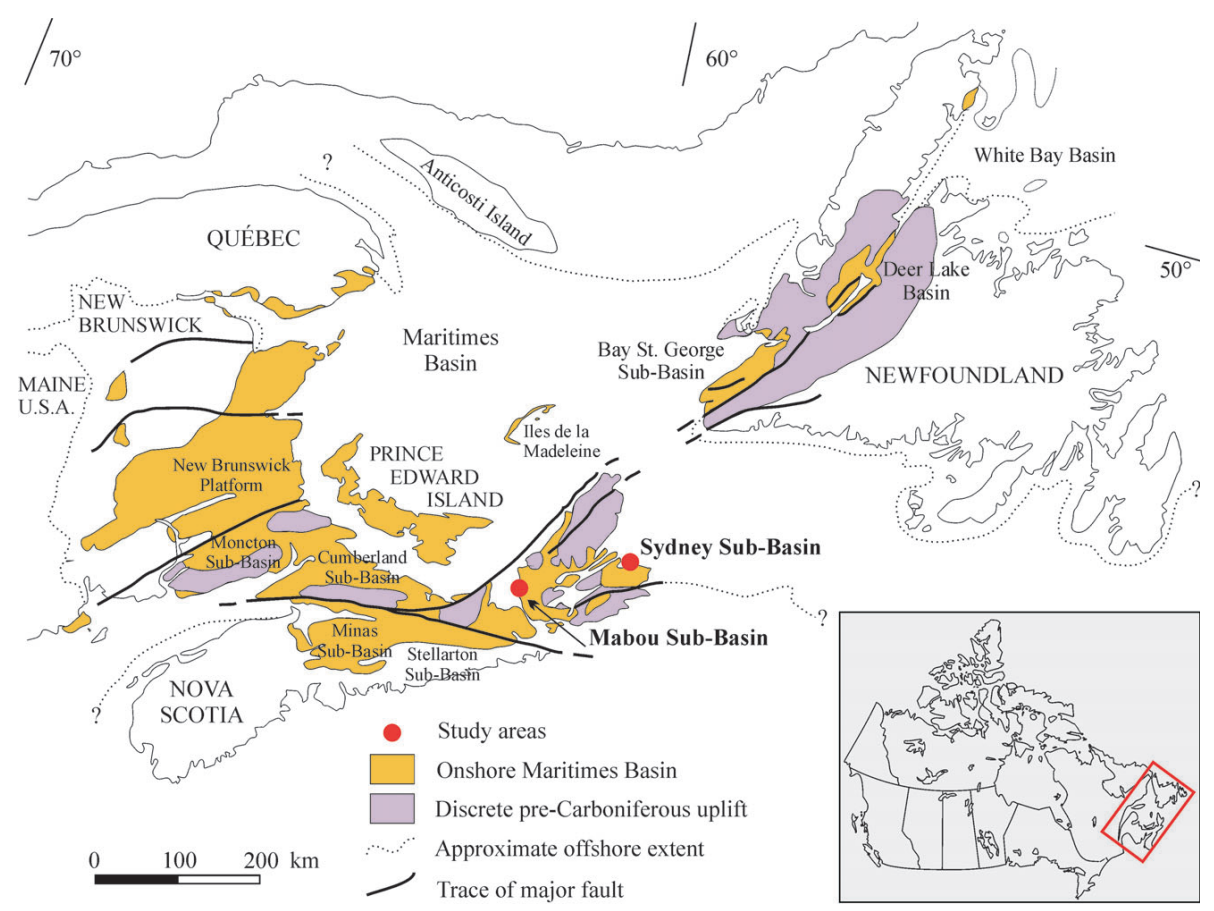

Figure 1. Location map of Sydney and Mabou, Nova Scotia, Minto, New Brunswick and Bay St. George, Newfoundland and Labrador Sub-Basins, Canada.

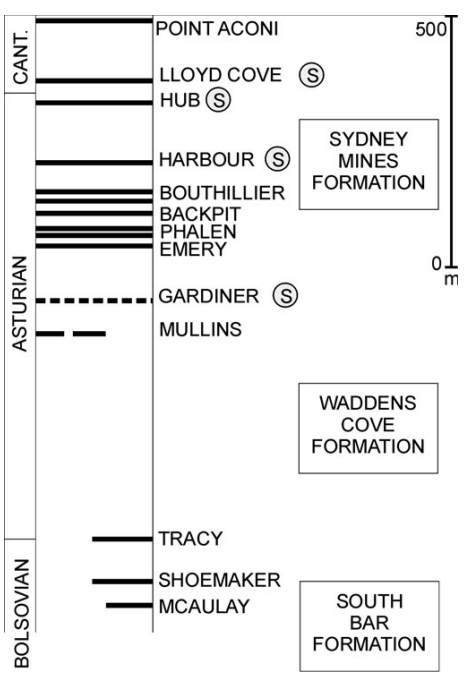

Figure 2. Coal Seams of Sydney Coalfield, Nova Scotia, Canada. "S" marks sampled roof rocks, where the coal-seam names are according to the Geological Survey of Canada (Bell 1938). Stratigraphic section of the Mabou Sub-Basin is omitted but see Zodrow \& Vasey (1986). to as CCs). Bornemann (1856) provided the impetus for the use of epidermal-fossil remnants in palaeobotanical studies. Subsequently, the cuticular coal that occurred in the Moscow Basin was named "Blätterkohle" by Auerbach \& Trautschold (1860, p. 26), and referred to as "Papierkohle" ("cuticles fossiles") by Zeiller (1882, p. 218) because of its textural characteristics resembling paper. Gothan (1916) also mentioned Carboniferous neuropterid cuticles. Neavel \& Miller (1960), Neaval \& Guennel (1960) and DiMichele et al. (1984) studied Indiana "paper coal", where the latter authors referenced natural maceration as a fossilization process for the stems of Karinopteris sp. (see also Stach 1982, pp. 114, 115). Giannasi \& Niklas (1977) and Lockheart et al. (2000) referenced angiospermous oak and elm-tree cuticular sheaths of Miocene age. The Permian Döhlener Basin, Germany, is also known for these cuticles (Barthel 1976, Reichel \& Schauer 2006). Looy (2007, p. 959) referenced mineralized cuticles (= fossilized cuticles three-dimensionally preserved by carbonate impregnation) without supportive mineralogic and geochemical data. Recently, "paper coal", similar to that from Indiana, has been discovered in Upper Triassic sediments in Cacheuta, Argentina (pers. comm. Dr. J.A. D’ Angelo, January 2008). This short summary illustrates (1) the lack of a consistent nomenclature, and (2) contributes to confusion about what is meant by "fossilized cuticle", or "paper coal". To address this problem requires a theoretical framework in which certain classification questions can be addressed (e.g., whether post-diagenetic influences should be a part of the model, consistent nomenclature), but from which also emerges a clear concept of the primary fossilization process involved, in relation to other processes of plant preservation. In effect, such a theoretical framework would eventually lead to a basic reassessment and revision of Schopf's (1975) classic classification of fossilization processes.

In this paper, we discuss the origin of FCs, based specifically on data originating from the Sydney Coalfield, Nova Scotia, although other Carboniferous Maritimes Sub-Basins provided ancillary data, i.e., Mabou, Nova Scotia, Minto, New Brunswick, and Bay St. Georges in southwestern Newfoundland (Fig. 1).

\section{Materials}

From more than 170 FCs collected, 151 glass-mounted slides were made all of which are curated in the Palaeobotanical Fossil Collection at Cape Breton University. This includes 20 types and figured specimens. These represent only $c a$ $1 \%$ of the 15,000 compressed fossil plants collected from the Sydney Coalfield (Table 1), but they include all of the major floral groups. From this collection, Alethopteris ambigua (Lesquereux pars) Zodrow \& Cleal, 1998, and Cordaites principalis (Germar) Zodrow et al., 2000 were selected for study because they are represented both by FCs and CCs. In addition, the only collected cuticle-fossilized medullosalean(?) axis, $4 \mathrm{~cm}$ long and $0.75 \mathrm{~cm}$ wide, is included in the 
study. These samples originated from the clay-rich roof rocks, Table 2 (see also Zodrow 1983) in the Sydney Mines Formation (Fig. 2), Sydney Coalfield (Cleal et al. 2003). Associated coal seams show random vitrinite reflectance (Ro \%) between $0.70 \%$ to $0.75 \%$ (Hacquebard \& Cameron 1989, Fig. 15); however, our measurements at point of sampling show lower values (i.e., $0.60 \%$ to $0.65 \%$ ).

A few samples of Indiana and Argentine "paper coals" (cuticular sheaths or envelopes devoid of coal) were also examined for an initial comparison with Sydney's FCs, though results will be published later.

\section{Methods}

Table 3 documents (1) the chemical treatments of samples studied, together with (2) ratios calculated from integrated areas under the absorbance curves (Zodrow \& Mastalerz 2007) from Fourier transform infrared spectroscopy (FTIR) technique.

(1) FCs of A. ambigua (Lesquereux pars) were freed from the shale matrix using $48-51 \% \mathrm{HF}$, and CCs of this species were macerated using a modified protocol of Schulze's process which is suitable for Sydney's compression fossils (Cleal \& Zodrow 1989). The FCs of $C$. principalis (Germar) and the cuticle-fossilized medullosalean(?) axis were physically lifted dry from the shale matrices, and subdivided into three parts for independent analyses.

(2) $\mathrm{CH}_{2} / \mathrm{CH}_{3}$ is the methylenic/methyl ratio (Fig. 3) calculated in the aliphatic stretching region of $2800 \mathrm{~cm}^{-1}$ to $3000 \mathrm{~cm}^{-1}$ wavenumber. Smaller ratios indicate more branched and shorter aliphatic chains, whereas from larger ratios longer unbranched chains may be inferred (see Van Bergen et al. 2004). $\mathrm{Al} / \mathrm{O}_{\mathrm{x}}$ is the ratio of the integration area of the aliphatic stretching region of $2800 \mathrm{~cm}^{-1}$ to $3000 \mathrm{~cm}^{-1}$ to that of the oxygenated groups in the
Table 1. Overview of generic taxa (number of species bracketed) represented by fossilized cuticles. Carboniferous Maritimes Basin, Canada

\begin{tabular}{ll}
\hline \multicolumn{2}{c}{ Morphogenus } \\
\hline Sydney Coalfield, Nova Scotia: \\
Annularia (1) & Mariopteris (3?) \\
Alethopteris (3) & Neuropteris (4) \\
Aphlebia (2?) & Odontopteris (3) \\
Calamites (?) & Oligocarpia (2) \\
Cordaites (1) & Pecopteris (5) \\
Cyclopteris (2) & Reticulopteris (1) \\
Laveineopteris (1) & Sphenophyllum (4?) \\
Linopteris (2) & Eusphenopteris (2) \\
Lobatopteris (1) & Sphenopteris (?) \\
Lonchopteris (1) & Lepidodendron (?) \\
Macroneuropteris (3) & \\
\hline Minto Coalfield, New Brunswick: & \\
Mariopteris (2?) & Neuropteris (?) \\
\hline Bay St. Georges Basin, Newfoundland and Labrador: \\
Lobatopteris (1)
\end{tabular}

$1600 \mathrm{~cm}^{-1}$ to $1800 \mathrm{~cm}^{-1}$ region. From this ratio the oxidation state of the cuticle may be inferred (Pradier et al. 1992, Lin \& Ritz 1993, Zodrow \& Mastalerz 2007).

Samples for FTIR analysis were prepared by mixing $0.5 \mathrm{mg}$ to $2 \mathrm{mg}$ of the dry cuticle material with $\mathrm{ca} 250 \mathrm{mg}$ $\mathrm{KBr}$ and pressing this mixture into pellets. The $\mathrm{KBr}$ pellets were then analyzed on a Nicolet $20 \mathrm{SXC}$, equipped with a DTGS detector, collecting 1,024 scans/samples at a resolution of $4 \mathrm{~cm}^{-1}$ wavenumber which were recorded in the $400 \mathrm{~cm}^{-1}$ to $4000 \mathrm{~cm}^{-1}$ region.

Elemental analyses were performed on a Carlo Erba 1108 CHNS-O Elemental Analyzer using $1 \mathrm{mg}$ to $3 \mathrm{mg}$ of dried cuticles for analysis. Duplicates were performed to test for cuticular homogeneity.

Table 2. Semi-quantitative X-ray mineralogic data (wt.\%), grain sizes, and rock types of some roof rocks sampled. Sydney Mines Formation (Fig. 2), Sydney Coalfield, Nova Scotia. Detection limit is 1 to $3 \mathrm{wt} . \%$. Amorphous matter wt.\% is rather approximate, but the numbers imply large amounts of organics in these lithologies, confirmed as unidentifiable plant debris, spores and megaspores by thin-section examination. qtz - quartz, mi - mica/illite, chl - chlorite

\begin{tabular}{|c|c|c|c|c|c|c|c|c|}
\hline \multirow{2}{*}{$\begin{array}{l}\text { coal seam stratigraphic sample } \\
\text { position above the seam }\end{array}$} & \multicolumn{3}{|c|}{ mineral species } & \multicolumn{3}{|c|}{ maximum grain size $(\mathrm{mm})$} & \multirow{2}{*}{$\begin{array}{l}\text { amorphous } \\
\text { matter }\end{array}$} & \multirow{2}{*}{ rock type } \\
\hline & qtz & $\mathrm{mi}$ & chl & qtz & $\mathrm{mi}$ & chl & & \\
\hline \multicolumn{9}{|l|}{ Lloyd Cove } \\
\hline $10 \mathrm{~m}$ & 23 & 20 & $<10$ & 26 & 22 & - & $>40$ & clayey siltstone \\
\hline $100 \mathrm{~cm}$ & 24 & 32 & 38 & 78 & 160 & 55 & - & silty shale \\
\hline $20 \mathrm{~cm}$ & 25 & 25 & 15 & 80 & 165 & 57 & $>25$ & clayey siltstone \\
\hline \multicolumn{9}{|l|}{ Stubbart } \\
\hline $60 \mathrm{~cm}$ & 16 & 60 & 15 & 8 & 19 & 8 & $<15$ & shale \\
\hline \multicolumn{9}{|l|}{ Gardiner } \\
\hline $100 \mathrm{~cm}$ & 25 & 20 & 15 & 42 & 80 & 61 & $<35$ & clayey siltstone \\
\hline
\end{tabular}


Table 3. Fossilized cuticles (FCs) and their chemical treatments, cuticles by Schulze's process (CCs), and FTIR-calculated $\mathrm{CH}_{2} / \mathrm{CH}_{3}$ and $\mathrm{Al} / \mathrm{O}_{\mathrm{x}}$ ratios. Sydney Coalfield, Nova Scotia. * Zodrow et al. (2000, Table 3). 91-263 and SY-369 originated from the same stratal horizon at one locality in the roof rocks of the Lloyd Cove Seam (Fig. 2)

\begin{tabular}{|c|c|c|c|c|}
\hline $\begin{array}{c}\text { species } \\
\text { accession No. }\end{array}$ & $\mathrm{FC} / \mathrm{CC}$ & $\begin{array}{c}\text { chemical } \\
\text { treatment } \\
\text { (hours) }\end{array}$ & $\begin{array}{c}\mathrm{CH}_{2} / \mathrm{CH}_{3} \\
\text { aliphatic } \\
\text { chains }\end{array}$ & $\begin{array}{c}\mathrm{Al} / \mathrm{O}_{\mathrm{x}} \\
\text { oxygenated } \\
\text { groups }\end{array}$ \\
\hline \multicolumn{5}{|c|}{ Alethopteris ambigua } \\
\hline $91-240-0$ & $\mathrm{FC}$ & HF (10) & 4.87 & 0.76 \\
\hline $7-7 / 11-3 a$ & $\mathrm{CC}$ & - & 5.20 & 0.37 \\
\hline \multicolumn{5}{|c|}{ Cuticle-fossilized Medullosalean(?) axis } \\
\hline $7-9 / 27-9 b$ & $\mathrm{FC}$ & HF (15) & 7.01 & 1.77 \\
\hline $7-9 / 27-9 a$ & $\mathrm{FC}$ & Schulze's (15) & 4.83 & 0.52 \\
\hline $7-9 / 27-9 c$ & $\mathrm{FC}$ & $\mathrm{H}_{2} \mathrm{O}(10)$ & 4.51 & 1.77 \\
\hline \multicolumn{5}{|c|}{ Cordaites principalis } \\
\hline $91-263-0$ & $\mathrm{FC}$ & HF (24) & 5.80 & 1.77 \\
\hline $91-263-1$ & FC & Schulze's (24) & 4.18 & 0.32 \\
\hline $91-263$ & $\mathrm{FC}$ & $\mathrm{H}_{2} \mathrm{O}(10)$ & 3.50 & 0.66 \\
\hline SY-369* & $\mathrm{CC}$ & - & 2.80 & 0.30 \\
\hline
\end{tabular}

\section{Results: FTIR and elemental analyses}

\section{FTIR characteristics and influence by chemical treatments}

Figs 4 to 6 show the FTIR spectra of the samples studied. Relevant $\mathrm{CH}_{2} / \mathrm{CH}_{3}$ and $\mathrm{Al} / \mathrm{O}_{\mathrm{x}}$ ratios are summarized in Table 3, together with the chemical treatments applied.

By virtue of the sample, an opportunity exists (1) to compare infrared signals from FCs with CCs of the same species, and (2) to assess effects of Schulze's chemical treatmens on cutan moieties (Fig. 3) in FCs that were physically removed from the rock matrix without chemical intervention, i.e., the medullosalean(?) axis and $C$. principalis (Germar). Cutan is the biopolymer proposed as main constituent of fossil cuticles, but its complete structure is as yet unknown, either for extant plants or fossils (McKinney et al. 1996, fig. 5; Van Bergen et al. 2004). Although some data to this effect had been obtained from selected FCs by Zodrow \& Mastalerz (2001, Table 3), these data did not evaluate changes in cutan moieties, as is done in the present work.

In respect to (1) (comparison of infrared signals between FCs and CCs of the same species), two data sets are available. One is for A. ambigua (Lesquereux pars) (Fig. 4A, B and Table 3) which shows that differences in the $\mathrm{CH}_{2} / \mathrm{CH}_{3}$ ratios between $\mathrm{FCs}$ and $\mathrm{CCs}$ are small (perhaps insignificant), but that the $\mathrm{Al} / \mathrm{O}_{\mathrm{x}}$ ratios are significantly larger in FCs. This indicates an increase in oxygenated groups relative to aliphatic stretching bands as

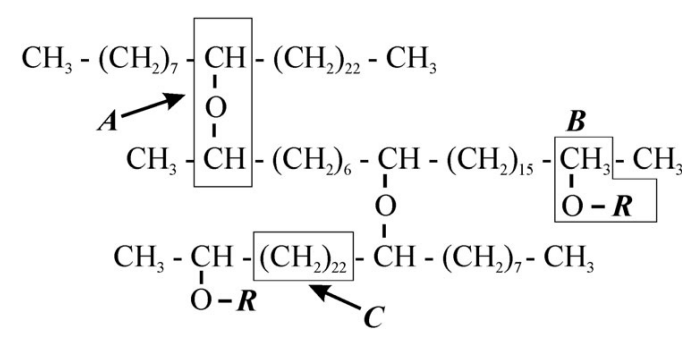

Figure 3. Organic moieties in the cutan biopolymer, simplified structure showing long-chain alkyl units linked by ether (Van Bergen et al. 2004, McKinney et al. 1996). A - ether linkage, B - ester or ether linkage (depending on $\mathrm{R}$ group), $\mathrm{C}$ - methylenic groups in long aliphatic hydrocarbon chains, $\mathrm{R}$ - monomer or $p$-coumaric acid.

a result of the chemical treatment. Interestingly, CCs for this species have a prominent peak at $1024 \mathrm{~cm}^{-1}$ wavenumber, which is not the case for FCs. A peak at this location of CCs could come from minerals matter or from $\mathrm{C}-\mathrm{O}$ bonds in alcohol. As mineral matter is expected to have been removed during chemical treatment (with HF), C-O is the postulated source. The lower $\mathrm{Al} / \mathrm{O}_{\mathrm{x}}$ ratio in FCs suggests relative enrichment in the oxygenated groups by the chemical treatment, and not diagnostic differences. The second set of data for (1) is for CCs C. principalis (Germar) (Fig. 5D) and FCs (Fig. 5C) treated only by water-washing. In this case, differences in both the $\mathrm{CH}_{2} / \mathrm{CH}_{3}$ and $\mathrm{Al} / \mathrm{O}_{\mathrm{x}}$ ratios are distinct, with each of the ratios being lower in $\mathrm{CCs}$. A lower $\mathrm{Al} / \mathrm{O}_{\mathrm{x}}$ ratio in CCs corresponds to that seen in A. ambigua (Lesquereux pars) (Fig. 4), again suggesting a relative reduction in aliphatic groups in favor of oxygenated groups during chemical treatment. A lower $\mathrm{CH}_{2} / \mathrm{CH}_{3}$ ratio in CCs of $C$. principalis (Germar) compared to Fig. 4A may suggest that chemical treatment shortened aliphatic chains, though this was not observed for $A$. ambigua (Lesquereux pars) (Fig. 4).

In respect to (2) (assessing the chemical effects on FCs), influence of Schulze's process is demonstrated on the cuticle-fossilized medullosalean(?) axis (Fig. 6A-C) and $C$. principalis (Germar) (Fig. 5A-C). Noted is that $\mathrm{CH}_{2} / \mathrm{CH}_{3}$ and $\mathrm{Al} / \mathrm{O}_{\mathrm{x}}$ ratios (Table 3) are consistently smaller in comparison with those after HF treatment, as noted in our previous study on FCs (Zodrow \& Mastalerz 2001, Table 3). These changes in ratios from Schulze's treatment result in loss of information, as seen in relatively reduced aliphatic moieties compared to the oxygenated functional groups, as well as in some elimination of longer-aliphatic chain compounds (see Fig. 3). However, in the cases where the FCs parts were treated only with distilled water, the $\mathrm{CH}_{2} / \mathrm{CH}_{3}$ ratio is comparatively the lowest, whereas the $\mathrm{Al} / \mathrm{O}_{\mathrm{x}}$ ratio is intermediate or equal to that after HF treatment. This result, after treatment with distilled water, is rather unexpected and requires further study. 
Table 4. Elemental analysis of Alethopteris ambigua as fossilized cuticle (FCs) and as cuticle by Schulze's process (CC) in weight percent (wt.\%). Sydney Coalfield, Nova Scotia. Average of two analyses. Oxygen by subtraction

\begin{tabular}{lccccl}
\hline accession No. & nitrogen & carbon & hydrogen & sulfur & oxygen \\
\hline 91-240-0 FC & 2.05 & 47.52 & 4.35 & 15.41 & na \\
7-11/7-3a CC & 3.69 & 49.98 & 5.36 & 0.28 & 40.67 \\
\hline
\end{tabular}

\section{Elemental data}

Table 4 shows elemental data of the FCs and CCs of A. ambigua (Lesquereux pars). Although carbon of CCs is comparable to that of FCs, in FCs both hydrogen and nitrogen levels are appreciably lower, whereas sulfur is very high. The high sulfur content is probably due to pyrite contamination, as other elemental analyses of cuticles from Sydney Coalfield showed low sulfur content ( 0.15 to $0.19 \mathrm{wt} . \%$, Zodrow et al. 2000, Table 4). Because of this unresolved situation, we refrained from calculating the oxygen component. However, the $40.67 \mathrm{wt} . \%$ oxygen level of CCs reported is nearly double that of all our previously reported oxygen analyses of cuticles $(\mathrm{n}=12$, Lyons et al. 1995, Table 1; Zodrow et al. 2000, Table 4), and requires further study.

\section{Nature and occurrence of fossilized cuticles in Sydney Coalfield}

\section{Preservation state}

A compressed pinnule (Fig. 7), or the mesophyllous component of the original leaf vitrinized during coalification, may have the cuticle well preserved (Fig. 8). In contrast, fully developed FCs specimens in the Sydney collection are characterized by the absence of the vitriniticcompressive component (Zodrow \& Mastalerz 2001), they are seen flatly adpressed on a rock matrix, and are not impregnated with any mineral matter [they have no third dimension as cuticles have described by Looy (2007)].

\section{Physical characteristics of FCs compared to CCs}

The amber color of fully developed FCs matches that of CCs, though significant physical differences exist between the two. One such difference is that FCs have waxy surfaces that makes them extremely water repellent, and on this account resemble over-macerated CCs, e.g., when maceration is repeated on CCs (including the alkaline treatment). Assuming that the molecular structure of the FCs, including multilayering, is similar to that of cuticles from extant plants, the water-repellent characteristic is probably explained by the presence of lipid layers that constitute a cuticle

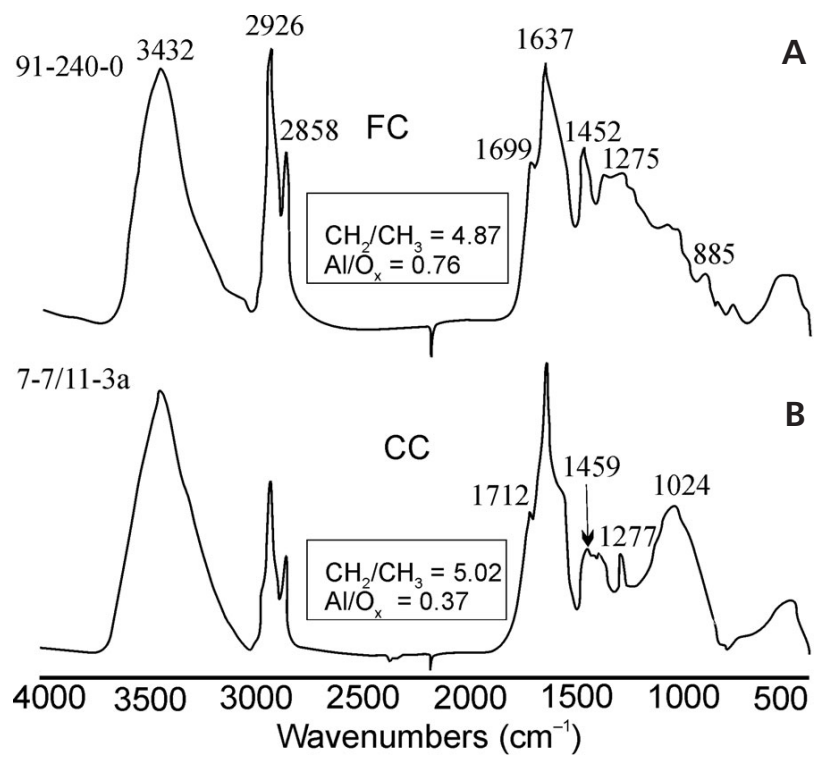

Figure 4. FTIR spectra. Alethopteris ambigua (Lesquereux pars) cuticles. - A - FC freed from the rock matrix by HF. 91-240-0. • B - CC. 7-11/7-3a. Lloyd Cove Seam, Sydney Coalfield, Nova Scotia.

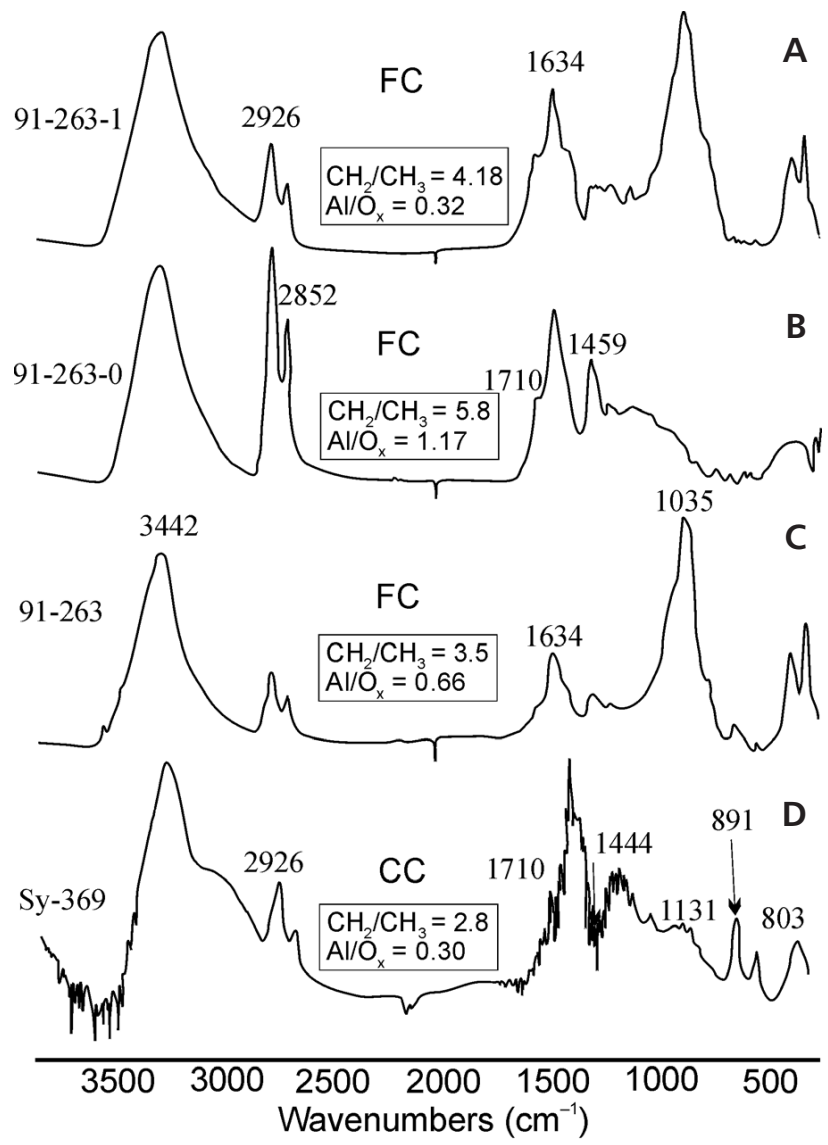

Figure 5. FTIR spectra. Cordaites principalis (Germar), cuticle. Chemical-treatment comparison. • A - FC treated by Schulze's process. • B - FC freed with HF. $\bullet$ C - FC distilled-water washed only. 91-263-1, 91-263-0, 91-263, respectively, contiguous specimen. - D - CC from Zodrow et al. (2000, fig. 3A). Lloyd Cove Seam, Sydney Coalfield, Nova Scotia. 

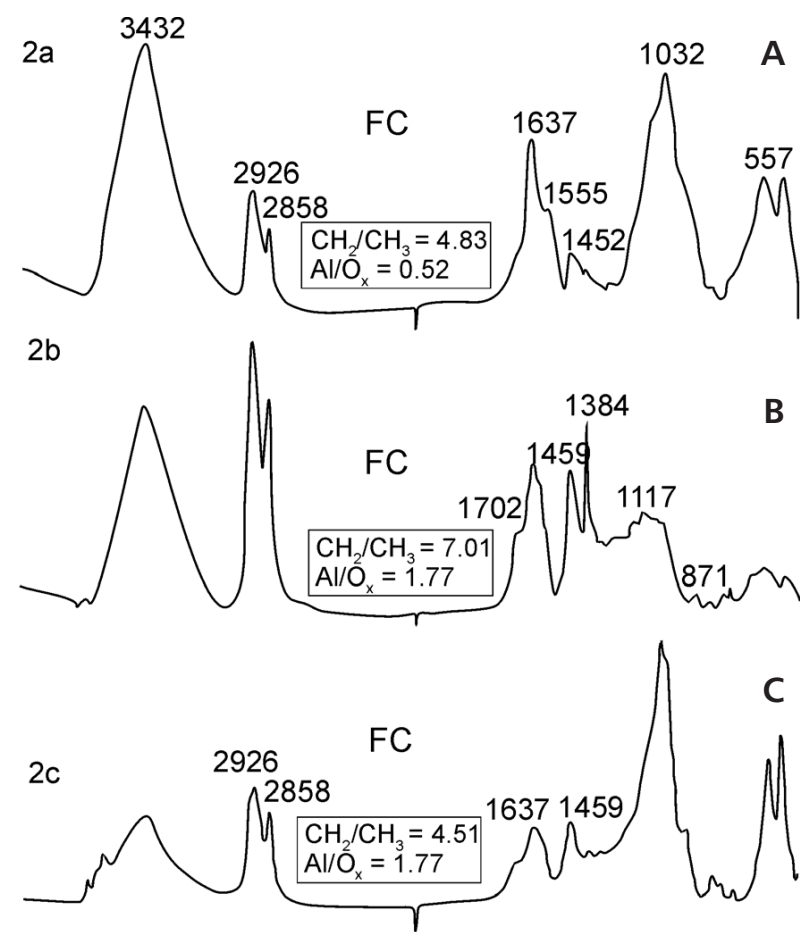

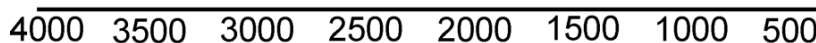 Wavenumbers $\left(\mathrm{cm}^{-1}\right)$}

Figure 6. FTIR spectra. Cuticle-fossilized medullosalean(?) axis. Comparisons of chemical treatments. $-\mathrm{A}-\mathrm{FC}$ treated by Schulze's process. - B - FC freed with HF. $\bullet$ C - FC distilled-water wash only. 7-9/27-9. Harbour Seam, Sydney Coalfield, Nova Scotia.

(Walton 1990, and references therein; Van Bergen et al. 2004). A second difference between FCs and CCs is that FCs are comparatively more static (more electrically charged), which makes it difficult to manipulate them, particularly when they are dry. A third difference reflects on the nature of preservation. For example, FCs of Linopteris obliqua (Bunbury) Zodrow, Tenchov \& Cleal, 2007 are entirely intact as are the FCs of Reticulopteris muensteri (Eichwald) Zodrow \& Cleal, 1993 (Fig. 9). In contrast, CCs of L. obliqua (Bunbury) consistently disintegrated upon maceration, completely or partially, along the reticulate venation into individual areolae (Fig. 10) (ELZ 2007, unpublished research). A satisfacory explanation for the integration is not available, but such phenomenon has not been observed in any other CCs studied (e.g., Cleal \& Zodrow 1989), and since then.

\section{Epicuticular preservation on FCs}

FCs may have preserved trichomes, papillae, and lateralvenation. Most noticeable, though, is that upper and lower surfaces are generally inseparable, which does not rule out preservation of only one fossilized surface. If only one sur-

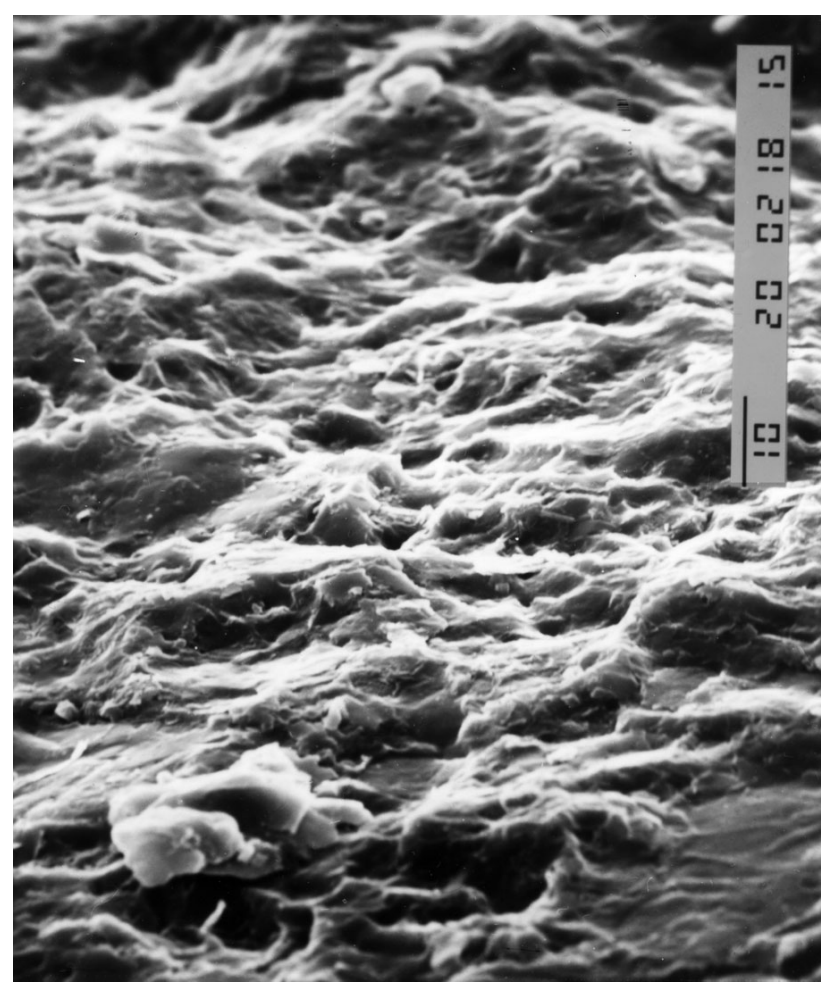

Figure 7. Oblique view (top to bottom) of the compressed leaf of the seed fern Macroneuropteris macrophylla (Brongniart). SEM stub \# 12, photo $2,40^{\circ}$ tilt, $\times 2,000,982-229$. Lloyd Cove Seam, Sydney Coalfield, Nova Scotia.

face is preserved, then it is likely the upper surface because it is generally thicker than the lower one. In either case, stomatal, costal and intercostal cells are seldom preserved, though three exceptions are noted from the Sydney Coalfield, i.e., R. muensteri (Eichwald), A. ambigua (Lesquereux pars), and Odontopteris cantabrica Wagner 1969. Cleal et al. (2007) compared FCs and CCs of specimens of O. cantabrica.

\section{FCs identification problem}

Careful field examination in the Maritimes Basin can in most cases differentiate between true compressions and true amber-colored FCs. However, as demonstrated later, "compressions" can be naturally macerated to varying degree. A subjective-state assessment would consist of transmission-microscope examination of the "compression" that had been freed from the rock matrix, immersed in distilled water or some other suitable medium. Conclusions reached, however, can be confounded by variable thickness of the compression, e.g., thin "compressions" of Alethopteris serlii (Brongniart) Zodrow \& Cleal, 1998 or Macroneuropteris scheuchzeri (Hoffmann) Cleal, Shute \& Zodrow, 1990, vs. thick "compres- 


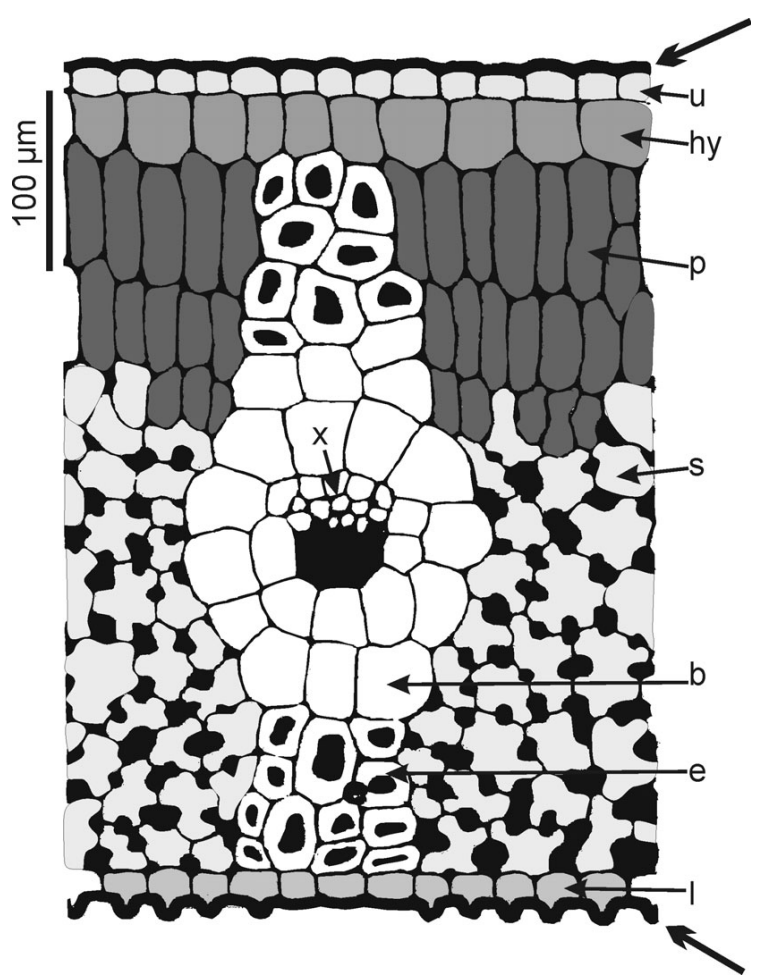

Figure 8. Histological cross section of the seed-fern leaf Alethopteris sullivantii Lesquereux, coal-ball preparation. Tissue between the upper and lower cuticle is termed mesophyll, where the cuticle is $\sim 5 \mu \mathrm{m}$ thick. (u) upper epidermis, (hy) hypoderm, (p) palisades, parenchyma, (x) xylem, (s) spongy parenchyma, (b) bundle sheath, (e) bundle-sheath extension, and (1) lower epidermis. After Reihman \& Schabilion (1976).

sions" of A. pseudograndinioides Zodrow \& Cleal, 1998, for example. A more objective assessment requires observing the blackening degree of the alkaline solvent (during Schulze's process), where the comparative scale is that completely macerated FCs do not discolor this colorless solution. The most conclusive approach, however, is by methods of liquid-state ${ }^{1} \mathrm{H}$ or ${ }^{13} \mathrm{C}$ NMR, or FTIR spectroscopy.

In practical terms, cuticles extracted from variably affected natural-macerated compressions (partial FCs/CCs), may inherently show poor-cell topography, which could be misinterpreted as having originated from "eroded" compression-state preservation which overlooks the true nature of the preservation and taphonomic histories.

\section{Geological observations on FCs in the Sydney Coalfield}

Geological field and experimental evidence gathered over the last three decades by ELZ is summarized below, in support of the proposed chemical model, ever since the late professor C.A. Arnold in 1975 pointed to the presence of FCs (Ptychcarpus unitus) from the Hub Seam in Sydney

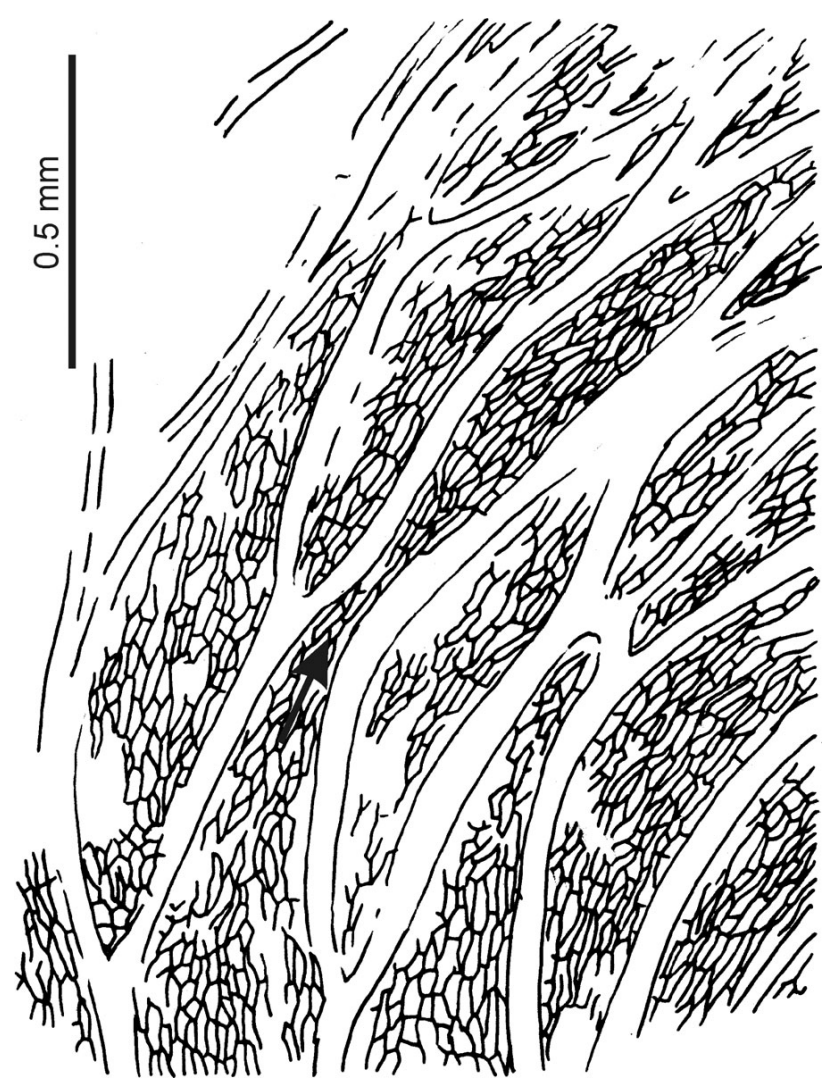

Figure 9. Reticulopteris muensteri (Eichwald). FC with discernible intercostal cellular structure. Three cells separate flexuous lateral veins (arrowed). 982-430D. Mabou Sub-Basin, Nova Scotia.

Coalfield (ELZ 1977, pers. comm.). Additional observations include data on vertical rock-joint distribution, results from thin-section analyses, sulfur determination in shale (Zodrow \& Mastalerz 2001, table 1), and most importantly the recognition of the role of oxidizing authigenic pyrite as an agent for change.

(1) FCs and compressions can be preserved side by side in a bedding plane which implies that localized genesis of FCs is possible.

(2) In addition to individual FCs, cuticle-pinnate structures of 30-cm length can be preserved. Included are frond segments of $O$. cantabrica Wagner (Zodrow 1985, pls 1-3), ferny sphenopteroid Oligocarpia brongniartii (Zodrow \& Mastalerz 2002, fig. 3), and larger pecopteroid structures from Newfoundland (Bashforth 2005, pl. 9, figs 1-3).

(3) Naturally macerated ferny and seed-fern axes are rare in comparison with FCs.

(4) FCs are fresh-looking and free from signs of alteration.

(5) FCs never show any siliciclastic mineral matter lodged between separable upper and lower surfaces, nor is it observed in the only collected axis that cannot be separated into surfaces. 


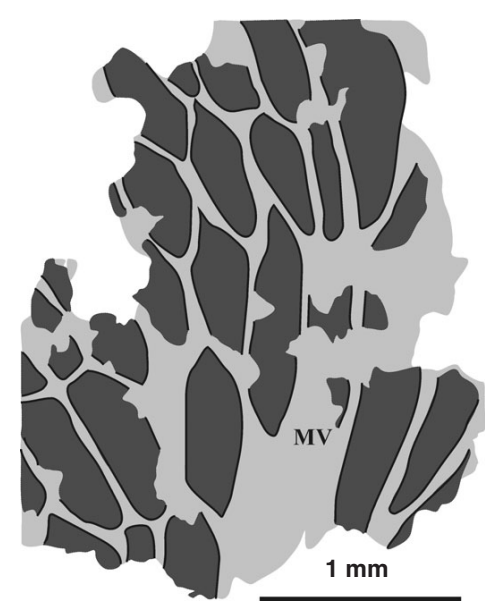

Figure 10. Linopteris obliqua (Bunbury), CC. Basal part of the pinnule fragmented into more or less loose areolae along lateral veins, after attempting maceration. $\mathrm{MV}$ is the remnant mid vein. 977-644-2. Hub (Stubbart) Seam, Sydney Coalfield.
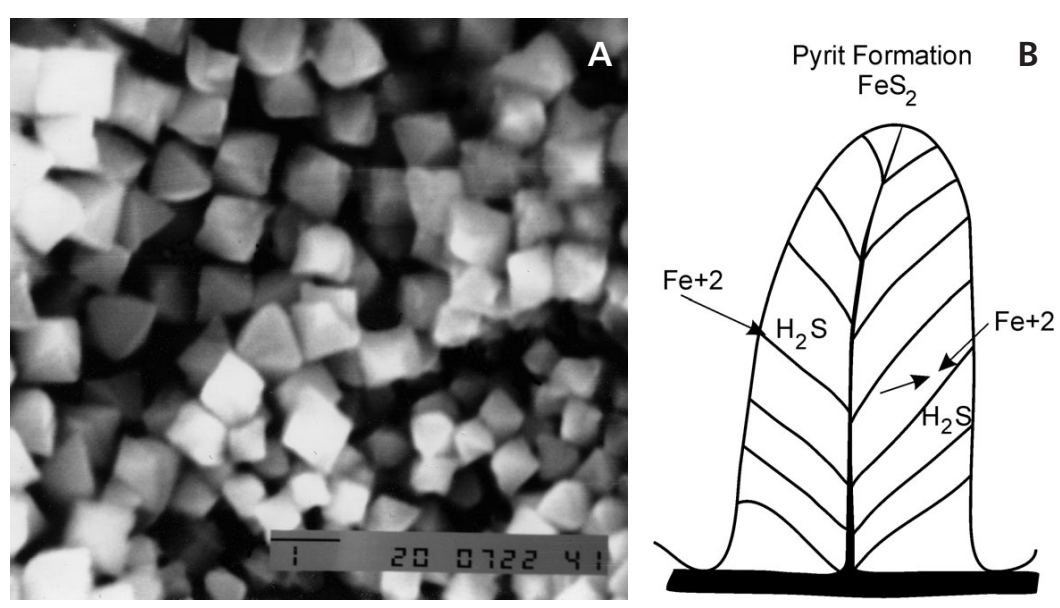

Figure 11. Authigenic-pyrite deposit on a compression. $\bullet \mathrm{A}-$ sub-micron sized cubes and octahedra of pyrite on the abaxial surface of Macroneuropteris scheuchzeri (Hoffmann). SEM stub \# 34, 982-376b, × 10,000. • B - pyrite formation on a Carboniferous foliar compression, modified after Berner (1980, figs 5-13; 1984). Lloyd Cove Seam, Sydney Coalfield, Nova Scotia.
(6) FCs are typically free from pyrite, as seen in situ and in FCs freed from the shale matrix. These contrasts sharply with compression fossils (with preserved cuticle) that may show massively deposited sub-micron-sized authigenic pyrite (Fig. 11), and siderite that are unaltered at time of collection (Zodrow et al. 2007).

(7) FCs with naturally macerated in situ sporangia and intact palynomorphs are rare (e.g., Zodrow et al. 2005). Rare are also in situ naturally macerated sporangia without preserved FCs, though recovered palynomorphs are intact for taxonomic determination.

(8) FCs are confined to argillaceous roof-rocks (Table 2), but areal distribution in any particular stratal locality is nearly impossible to circumscribe. One exception is a locality that was exposed by surface-coal mining in the basal Cantabrianat the Lloyd Cove Seam, a ca $5 \mathrm{~m}^{2}$ area. It yielded FCs of A. ambigua (Lesquereux pars), L. obliqua (Bunbury), P. unita (Brongniart), C. principalis (Germar), and Neuropteris flexuosa Sternberg. The other exception is found in the Mabou Sub-Basin where R. muensteri (Eichwald) is abundantly present in thick, oxidized shale units (Zodrow \& Cleal 1993, Zodrow \& Vasey 1986).

(9) FCs are absent in coarse-grained clastic rocks which include channel deposits that replaced roof shale (Fig. 12).

(10) Near the Westphalian D base, Fig. 2 (Zodrow \& Cleal 1985, fig. 5a), thermal maturity increased to Ro $0.85 \%$ or more (Hacquebard \& Cameron 1989, fig. 15). FCs are not known from below this boundary, though compression-cuticles are common (Zodrow \& Cleal 1998).

(11) Transitional phases between coalification-FCs over sub-mm distances in one compression leaflet can be observed and can be confirmed by infrared analysis on other specimens (Zodrow \& Mastalerz 2001, p. 272).

\section{Proposed origin of FCs in the Sydney Coalfield, Nova Scotia}

\section{Acid source for in situ maceration}

Essential for the pathway of FCs transformation is an in situ acid source that performed a function analogous to the acid phase of Schulze's process. This source is identified with the two-stage sulfuric acid production that takes place when in situ coal pyrite oxidizes at ambient conditions, with resulting orderly paragenesis of secondary, hydrated-sulfate minerals (Zodrow \& McCandlish 1978, Zodrow et al. 1979, Zodrow 1980; ELZ 1978-1989, unpublished research notes). This is expressed in the following equation, see Fig. 13: The oxidation reaction, which involves soluble ferric iron for crystallization to fibroferrite, can only proceed at higher acidic levels, as in this reaction. These secondary hydrated sulfate precipitates are not expected to be associated with FCs, as they are water-soluble (Palache et al. 1957, p. 395).

\section{Proposed chemical model}

This section summarizes the processes and geological events leading to the fossilization process of FCs. Favorable fossilization conditions, coupled with anoxic conditions for pyrite precipitation on compressions (Berner 1980, figs 5-13) prevailed in the Sydney Coalfield from time-to-time. Linked with Late Alleghanian compressive forces in the Appalachian orogen and basin inversion (Gibling et al. 2002, fig. 2; Gibling et al. 2004, p. 171) is the development of vertical joints intersecting with inclined joints that today are mappable as complex joint systems, 
Fig. 14 (ELZ 2006-2008, unpublished research notes). These sets of joints subtend at the top of coal seams. Erosional contact planes, even contacts between plant fossils or between lycophyte-root systems and the entombing rock matrix of roof rocks or shale splits, provided additional conduits for ground-water circulation (Taylor et al. 1998, p. 271). The circulating oxygen-enriched ground water (see Berner 1970, 1984) provided the chemical prerequisites for initiating pyrite oxidation and sulfuric acid reaction necessary to macerate the vitrinitic component of the compressed fossil. Under these conditions, loss of vitrinite is expected, preserving concomitantly the fatty FCs (summary: Van Bergen et al. 2004, p. 144; Derenne \& Largeau 2001). The local acid environment additionally provided protection from bacterial, fungal, or enzymatic attacks on FCs. This implies that FCs can be used as proxy for higher-level acidic conditions, post-coal deposition that prevailed from time-to-time in the roof rocks or shale splits.

\section{Discussion}

Krauskopf (1967, p. 416) warningly remarked that all formulated oxidation reactions of sulfides are "only approximate representations of a complex natural process", and Fig. 13 is no exception. However, congruency of this equation with in situ sulfate mineral paragenesis is firmly supported by observation of stage-by-stage phase transformation over time, starting with precursor pyrite in coal, or in roofrock bedding planes. The paragenetic-mineralization process fortuitously allowed in situ sampling of each of the phases for determining chemical identity, supported by X-ray powder-diffraction analyses to verify the unit-cell parameters. Independent confirmatory sources are found in in vitro reactions that duplicated the paragenetic sequence phaseby-phase (Fig. 13). Thus, the model is empirically circumscribed in its ability to produce sulfuric acid by in situ pyrite oxidation, in the presence of oxygen and water. Variants of the paragenetic sequences have been documented from exposed coal surfaces (ELZ 1979-1989, unpublished research notes): (1) pyrite-melanterite-fibroferrite-rhomboclase-copiapite (Fig. 15), where the rhomboclase phase is stable only in an acid geochemical environment (Palache et al. 1957, p. 436). Measurements of mine-acid effluence showed $\mathrm{pH}$ levels as low as 2 (ELZ 1978-1989, unpublished research notes), and (2) pyrite-sideronatrite-metasideronatrite.

It is important to note that in all of these sequences, soluble ferric iron is present in at least one of the paragenetic minerals which confirms that sulfuric-acid production has taken place in accordance with Fig. 13.

The assumption that the circulating ground water is oxygen-enriched is based on the hypothesis that the Carboniferous atmosphere attained a level of $36 \%$ oxygen (Berner et al. 2003). By Henry's Law, gas solubility is directly pro- portional to the partial pressure of the gas above the solution, and by assuming the same total atmospheric pressure today as in Carboniferous time, the oxygen enrichment factor is $36 / 20$, or 1.8 times as much dissolved oxygen. This could presumably be augmented if hydroxyl groups [(OH)-1] (Dill et al. 1997, p. 296) were available for the oxidation process. Noted is that pyritic oxidation is enhanced, as the increased surface area by the sub-micron pyrite size (Fig. 11A) promotes reaction rates (Daniels et al. 1996). The rates are likely additionally accelerated by the activity of sulfur-loving bacteria (Zodrow 2005) which raises the question whether the proposed model is not really a combination of organic-inorganic processes.

The presence of fresh, unaltered micron-sized pyrite deposits on compression organs, as has been frequently observed by ELZ over years of collecting in the Sydney Coalfield, implies absence of oxygen and water, preventing in situ pyritic oxidation. The variable natural maceration effects visibly observed over compressions/FCs, and detected by FTIR, are linked to uneven pyritic distribution and consequently to uneven oxidation. By comparison, Schulze's process routinely results in uniformly macerated cuticular surfaces (excepting axes and stomatal apparatuses as they tend to be more cutinized). Moreover, naturally macerated pteridospermous ovules have not been found in Sydney Coalfield, Nova Scotia, or Maritimes Basin, which may be explained by insufficient amounts of deposited authigenic pyrite to be able to macerate the mm-thick seed coat, though ovular cuticles are preserved (Cleal \& Zodrow 2009).

In situ preservation of naturally macerated sporangia without preserved FCs is at variance with the chemical model that is expected to produce FCs. This is particularly so as we do not know of any organic solvent, including ionic liquids (Novoselov et al. 2007), that would solubilize either cuticles of extant plants or FCs. It is known that raised heat levels, higher maturity levels, can obliterate the otherwise inert sporopolleninous spores (Traverse 1988, p. 43). That that is not the case for either the Sydney Coalfield or for the Maritimes Basin (Hacquebard 1997) is demonstrated by the excellent preservation of spores (Dolby 1988-1989). Comments are in order why (1) leaf laminae may not be preserved as FCs in the presence of preserved naturally macerated sporangia, (2) FCs are typically not separable into two surfaces, and why (3) FCs may not have preserved cellular or stomatal features. The non-preservation of the lamina of FCs (1) suggests that the model does not apply, i.e., genesis may be different, whereas (2) and (3) are expected results of the model and explained by removal of the vitrinized mesophyll by maceration that caused the cuticular sheath to collapse. Moreover, the collapse may also have pressed the surfaces tightly into one single unit, preventing clayey or other debris from entering, and also could have contributed to obscuring impression of epidermal features onto the cuticle (Fig. 8). 


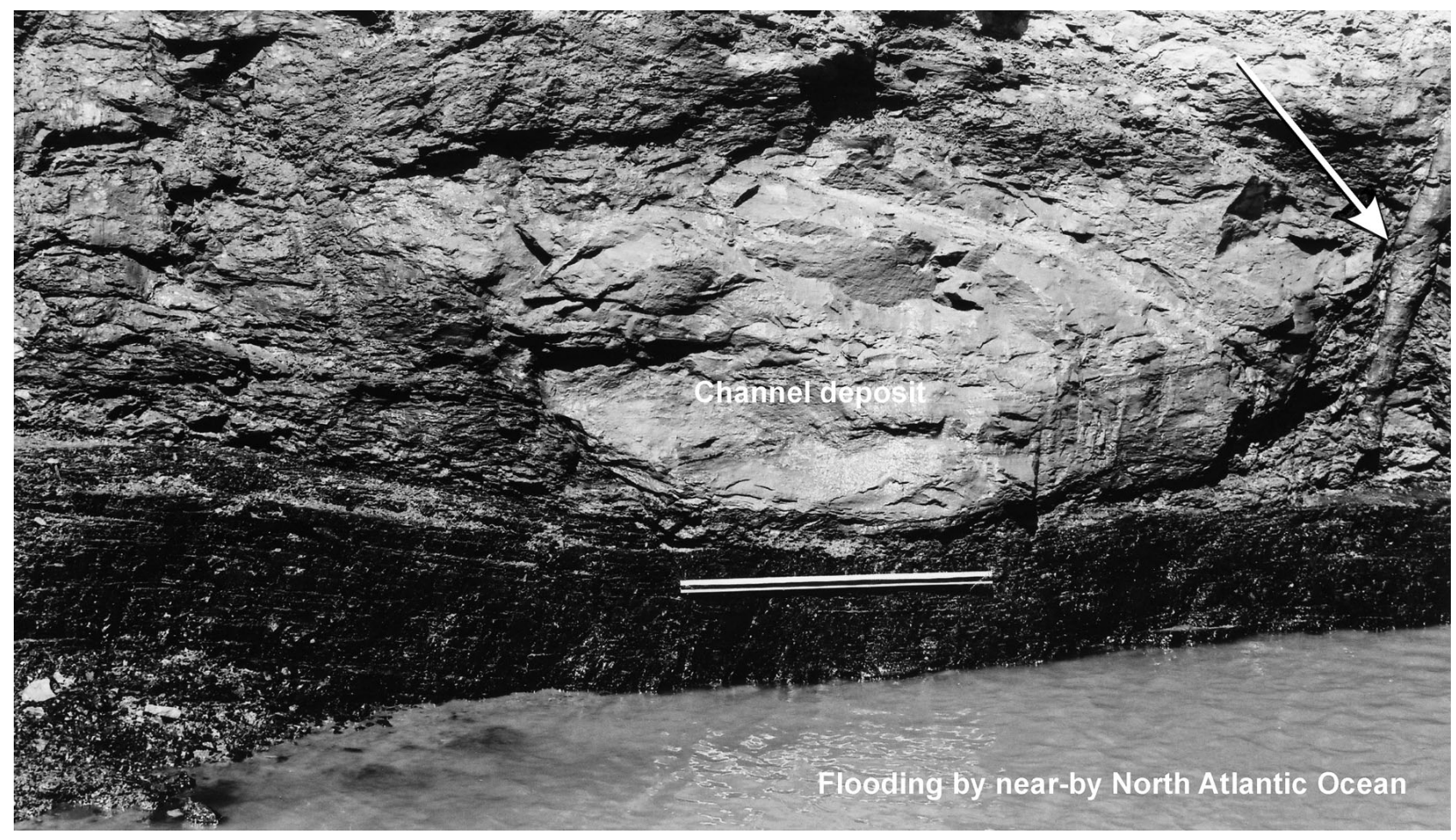

Figure 12. Fluviatile channel flanked by in situ calamites (arrowed) as roof-rock replacement in the Lloyd Cove Seam at the base of the Cantabrian Sub-Stage (Fig. 2). Sydney Coalfield, Nova Scotia. Scale bar is the 1-meter stick.

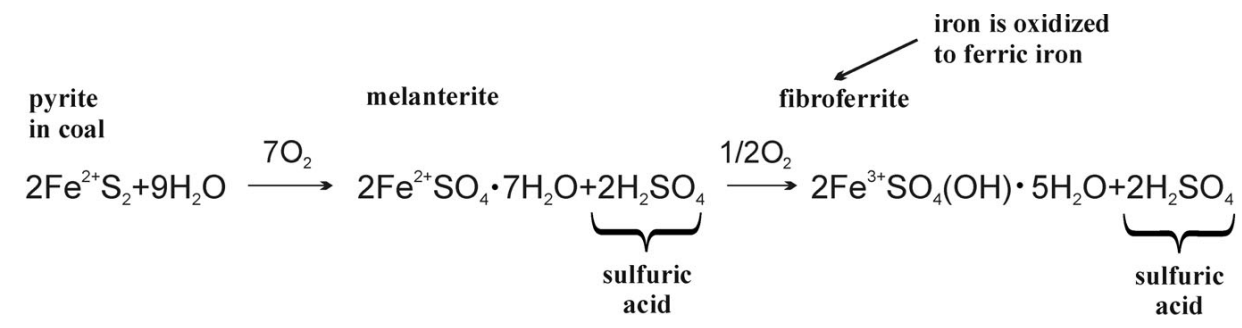

Figure 13. The oxidation reaction, which involves soluble ferric iron for crystallization to fibroferrite, can only proceed at higher acidic levels, as in this reaction.

The FTIR-derived $\mathrm{CH}_{2} / \mathrm{CH}_{3}$ and $\mathrm{Al} / \mathrm{O}_{\mathrm{x}}$ ratios have generally not been helpful in discriminating between FCs and CCs of A. ambigua (Lesquereux pars) and C. principalis (Germar), particularly as we have been unable to document more definitive changes in the moieties due to Schulze's chemical treatment at this level of sample population. Though differences of infrared signals between these two preservation states are subtly indicated, and increase of the oxygenated groups relative to the aliphatic hydrogen groups (and slight shortening of aliphatic chains) are evident. These differences are ascribed due to the chemical treatments. For example, changes in $\mathrm{CH}_{2} / \mathrm{CH}_{3}$ ratios occur in some instances, but in others they are not definitive.

Elemental data relating to A. ambigua (Lesquereux pars), though distinguished by different pathway of organic transformations of FCs and CCs, are ambiguous discriminators because of interfering high-sulfur content in
FCs which requires further clarification before a scientifically meaningful comparison is possible.

Although, generally speaking, FCs have advantages, FCs are also recognized to have certain disadvantages over CCs. The latter relate to information loss due to the non-preserved vitrinized mesophyll that could have been obtained from the acid and alkaline solutions from Schulze's process (ELZ 2008, unpublished research notes). The significance of this novel sampling methodology is that these solutions, as proxy for cuticle-free compression, could be studied by means of liquid-state proton $\left({ }^{1} \mathrm{H}\right)$, liquid-state FTIR spectroscopies, and high-performance liquid chromatography coupled with tandem mass spectrometers (ELZ 2007-2008, unpublished research notes). Information by these high-tech instruments relates to aliphatic/aromatic ratios, $\mathrm{C}-\mathrm{H}$ and other moieties, and $\mathrm{CH}_{2} / \mathrm{CH}_{3}$ and aliphatic/oxygenated groups ratios (Sobkowiak \& Painter 1992, D'Angelo \& 

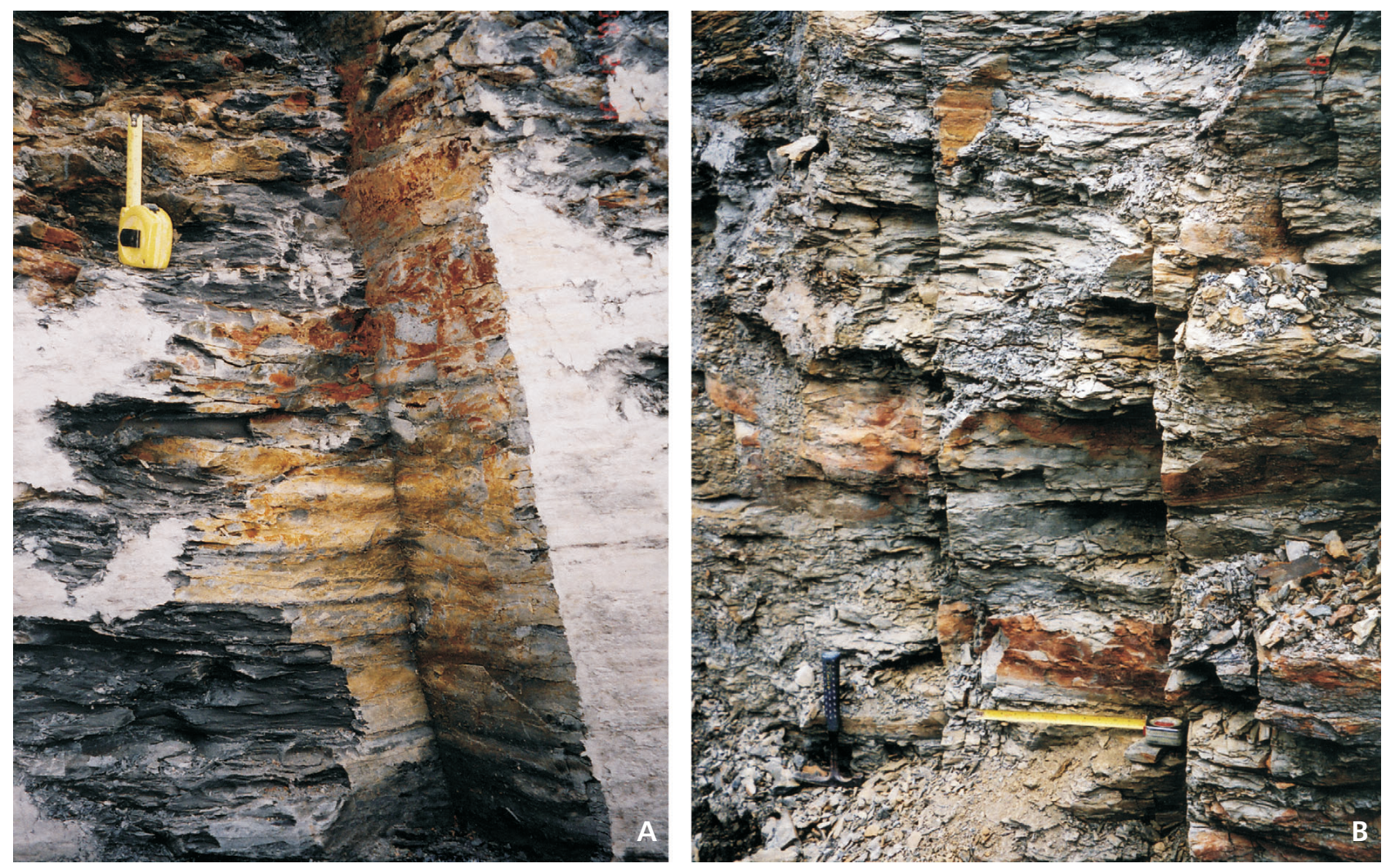

Figure 14. System of vertical sets of joints at the Carboniferous unconformity, Pleistocene-Asturian boundary, top of photograph. The joints do not extend into the coal seam. $\bullet$ A - joint intersection near $90^{\circ}$. Scale-tape measure is $10 \mathrm{~cm}$. $\bullet \mathrm{B}$ - closely spaced system of joints, variably separated from $3 \mathrm{~cm}$ to $41 \mathrm{~cm}$ (horizontal tape measure). Hub (Stubbart) Seam, Sydney Coalfield, Nova Scotia.

Marchevsky 2004, Zodrow \& Mastalerz 2007, D’Angelo 2006, table 1, p. 677).

An alternative to the chemical model proposed is a process that could have caused physical detachment of the vitrinitic part of the compression from the preserved cuticle. This process is presumably exemplified by the karinopterid axes of the Indiana "paper coal" which contain rock debris inside the cuticular sheaths, where each of the surfaces retained well-preserved impressions of elongate-epidermal cells (DiMichele et al. 1984, p. 629; Neaval \& Guennel 1960; ELZ 2008, unpublished research notes). However, samples of karinopterid foliage could not be separated into upper and lower surfaces, and additionally showed no cellular or stomatal preservations. Similar observations hold true for the "paper coal" from Cacheuta, Argentina (ELZ 2008, unpublished research notes). This situation is at odds with certain observations underpinning the proposed chemical model [e.g., see Geological observations on FCs in the Sydney Coalfield, points 5) and 6)], and refutes physical detachment of vitrinite from cuticular sheaths in Sydney Coalfield to preserve FCs, as they are.

Questions may arise about why vitrinite is preserved in the presence of pyrite in coal beds, if pyritic oxidation triggers "dissolution" of the vitrinitic mesophyll to generate FCs in the roof-rock. Such questions neglect to consider sa- lient factors of the geochemistry of pyrite [in the presence of organic matter] that in the absence of water and oxygen oxidation cannot take place.

In summary, the proposed chemical model of the origin of FCs is based on the late diagenetic to post-diagenetic interventions idiosyncratic of the Sydney Coalfield, Maritimes Basin. In general, it is suggested that the relationship between CCs and FCs probably parallels that between coal and non-coaly kerogen (Forsman 1963, p. 173, fig. 4; Van Denbroucke \& Largeau 2007, pp. 772, 774).

\section{Conclusion}

The definition of FCs occurring in the Sydney Coalfield, or Maritimes Basin, Canada, is linked to a chemical model and its ability to generate in situ acid for maceration of plant organs to fossilized cuticles, analogously to Schulze's process, where timing is late to post-diagenetic. Observed vertical distribution of FCs in the Sydney Coalfield suggests that, as a result of burial depth, increased maturity levels limited preservation to the youngest strata. In these strata, the fossilization process is localized in roof shale (and shale splits), and compressions are not always evenly macerated which is related to irregular authigenic-pyrite deposition. It follows 


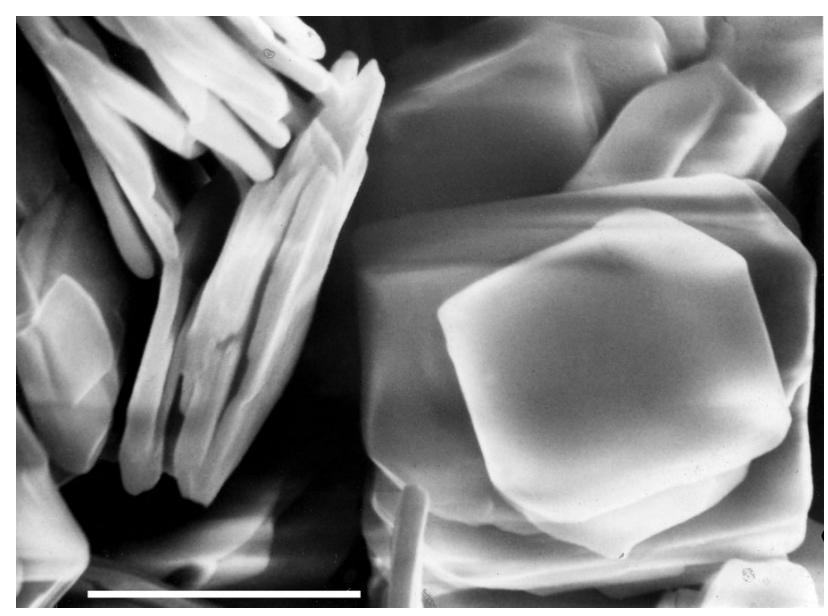

Figure 15. Paragenetic aluminocopiapite crystals after in situ pyritic oxidation in coal, tabular crystal habit, triclinic, pinacoidal $\{010\}$. SEM-stub documentation is lost. Hub (Stubbart) Seam, Sydney Coalfield, Nova Scotia. Scale bar is $10 \mu \mathrm{m}$.

that the designation of "coalified compression", unless investigated for variable-stage natural maceration, conveys ambiguity in respect to the spectrum of "pure compression" to "pure fossilized cuticle".

The proposed chemical model is a working hypothesis, as it is based only on data pertaining to the Sydney Coalfield. It is suggested that for the development of a comprehensive theory of fossilized cuticles, the worldwide and the vertical distributions of cuticular envelopes, compression-free cuticles, "paper coal" require study. Included in the study would be genesis, timing and determination of late to post-diagenetic influences from which a consistent nomenclature would follow. Additionally, infrared and nuclear-magnetic resonance investigations would lead to a clearer understanding of any possible biochemical differences involving the same species between FCs and CCs to underpin consistent nomenclature.

\section{Acknowledgments}

This study is dedicated to the late C.A. Arnold, Emeritus Professor of Botany, Emeritus Curator, Michigan State University, who in 1977 pointed out to ELZ that so little was known about the fossilization process of preserved Carboniferous cuticles.

Gratefully acknowledged are the journal's reviewers J.A. D’Angelo (Área de Química, Instituto de Ciencias Básicas, Universidad Nacional de Cuyo, Ciudad Universitaria), and W.A. DiMichele (Smithsonian Institution, Palaeobiology, Washington) for stimulating suggestions to improve both substance and presentation of this paper, and for providing some research literature. The authors thankfully acknowledge J. Pšenička for redrawing and improving a number of figures in the text. D. Keefe (Molecular Spectroscopy Research Laboratory, Department of Chemistry, Cape Breton University) is acknowledged for advice regarding certain chemical questions, and Zhifeng Gao (formerly post-doc- toral fellow, palaeobotany, Cape Breton University) for extensive SEM imaging of pyrite, aluminocopiapite, and seed-fern compressions from Sydney Coalfield, Nova Scotia. Funds for the elemental analysis were provided by the office of the Dean of Research, H.J. Johnstone, Cape Breton University. Finally, we are grateful to J. O'Donnell for editing this paper.

\section{References}

AuERBACH, J. \& TRAUTSCHOLD, H. 1860. Über die Kohlen von Central-Russland. Nouvelle Mémoire de la Société Imperiale des Naturalistes de Moscou 13, 1-58.

BARTHEL, M. 1962. Epidermisuntersuchungen an einingen inkohlten Pteridospermenblättern des Oberkarbons und Perms. Geologie Beiheft 11, 1-140.

BARTHEL, M. 1976. Die Rotliegendflora Sachsens. 190 pp. Abhandlungen des Staatlichen Museums für Mineralogie und Geologie zu Dresden. Theodor Steinkopff, Dresden.

BASHFORTH, A.R. 2005. Late Carboniferous (Bolsovian) macroflora from the Barachois Group, Bay St. George Basin, southwestern Newfoundland, Canada. Palaeontographica Canadiana 24, 1-81.

BELL, W.A. 1938. Fossil flora of Sydney Coalfield, Nova Scotia. Geological Survey Memoir 215, 1-334.

BERNER, R.A. 1970. Sedimentary pyrite formation. American Journal of Science 268 (January), 1-23.

BERNER, R.A. 1980. Early diagenesis: A theoretical approach. 241 pp. Princeton University Press, Princeton, N.J.

BERNER, R.A. 1984. Sedimentary pyrite formation: An update. Geochimica et Cosmochimica Acta 48, 605-615. DOI 10.1016/0016-7037(84)90089-9

BERNER, R.A., BEERLING, D.J., DUDLEY, R., ROBINSON, J.M. \& WILDMAN, R.A., JR. 2003. Phanerozoic atmospheric oxygen. Annual Review of Earth and Planetary Sciences 31, 105-134. DOI 10.1146/annurev.earth.31.100901.141329

BORNEMANN, G. 1856. Über organische Reste der Lettenkohlengruppe Thürigens. Ein Beitrag zur Fauna und Flora dieser Formation besonders über fossile Cycadeen, nebst vergleichenden Untersuchungen über die Blattstruktur der jetzweiligen Cycadeengattungen. 85 pp. Engelman, Leipzig.

ClEAL, C.J. \& ZODROW, E.L. 1989. Epidermal structure of some medullosan Neuropteris foliage from the Middle and Upper Carboniferous of Canada and Germany. Palaeontology 32(4), 837-882.

CleAL, C.J. \& ZoDROW, E.L. 2009 (in print). An association of Alethopteris foliage, Trigonocarpus ovules and Bernaultia-like pollen organs from the Middle Pennsylvanian of Nova Scotia. Palaeontographica, Abteilung $B$.

Cleal, C.J., Dimitrova, T.K. \& Zodrow, E.L. 2003. Macrofloral and palynological criteria for recognising the Westphalian-Stephanian boundary. Newsletter of Stratigraphy 39(2/3), 181-208.

Cleal, C.J., ShUTE, C.H. \& ZodROW, E.L. 1990. A revised taxonomy for Palaeozoic neuropterid foliage. Taxon 39(3), 486-492. DOI 10.2307/1223109

ClEAL, C.J., ZODROW, E.L. \& ŠIMƯNEK, Z., 2007. Leaf cuticles from the Pennsylvanian-aged medullosalean Odontopteris cantabrica. Argumenta Palaeonbotanica 47(2), 327-337. 
Daniels, W.L., Stewart, B. \& Dove, D. 1996. Reclamation of coal refuse disposal areas. 39 pp. Virginia Tech, Publication Number 460-131, June 1996.

D'ANGELO, J.A. 2006. Analysis by Fourier transform infrared spectroscopy of Johnstonia (Corystospermales, Corystospermaceae) cuticles and compressions from the Triassic of Cacheuta, Mendoza, Argentina. AMEGHINIANA 43(4), 669-685.

D'ANGELO, J. \& MARCHEVSKY, E. 2004. FTIR determination of aliphatic and aromatic $\mathrm{C}$-H contents of fossil leaf compressions PART I: Analysis, curve-resolving and choice of bands. Anuario Latinoamericano de Educatión Quimica (ALDEQ), San Luis, Argentina (2003-2005) 17, 37-41.

DERENNE, S., \& LARGEAU, C. 2001. A review of some important families of refractory macromolecules: Composition, origin, and fate in soils and sediments. Soil Science 166(11), 833-847. DO1 10.1097/00010694-200111000-00008

DiLl, H.G., EBERHARD, E. \& HARTMAN, B. 1997. Use of variations in unit cell length, reflectance and hardness for determining the origin of Fe disulphides in sedimentary rocks. Sedimentary Geology 107, 281-301.

DOI 10.1016/S0037-0738(96)00031-0

DiMichele, W.A., Rischbieter, M.O., EgGert, D.L. \& GASTALDO, R.A. 1984. Stem and leaf cuticle of Karinopteris: Source of cuticles from the Indiana "paper" coal. American Journal of Botany 71(5), 626-637. DO1 10.2307/2443359

DoLBY, G. 1988-1989. The palynology of the Morien Group, Sydney Basin, Cape Breton Island, Nova Scotia. Open Report, Nova Scotia Department of Mines, Halifax.

FORSMAN, J.P. 1963. Geochemistry of kerogen, 148-182. In BREger, I.A. (ed.) Organic Chemistry. Earth Series Monograph 16. Pergamon Press, Oxford.

GIANNASI, D.E. \& NIKLAS, K.J. 1977. Flavonoid and other chemical constituents of fossil Miocene Celtis and Ulmus (Succor Creek flora). Science 197, 765-767. DOI 10.1126/science.197.4305.765

Gibling, M.R., LANGenberG, W., Kalkreuth, J.W.F., WALDRON, R., COURTNEY, R., PAUL, J. \& GRIST, A.M. 2002. Deformation of Upper Carboniferous coal measures in the Sydney Basin: evidence for the late Alleghanian tectonism in Atlantic Canada. Canadian Journal of Earth Sciences 39, 79-93. DOI $10.1139 / \mathrm{e} 01-062$

Gibling, M.R., SAunders, K.I., Tibert, N.E. \& White, J.A. 2004. Sequence sets, high-accommodation events, and the coal window in the Carboniferous Sydney Coalfield, Atlantic Canada. In PASHIN, J.C. \& GASTALDO, R.A. (eds) Sequence stratigraphy, paleoclimate, and tectonics of coal-bearing strata. AAPG Studies in Geology 51, 169-197.

GÖPPERT, H.R. 1841. Die Gattungen der fossilen Pflanzen. Nonpaginated, pls I- XVIII. Bonn.

GotHAN, W. 1916. Über die Epidermen einiger Neuropteriden des Carbons. Jahrbuch königl. Preussischen Geologischen Landesamt, Berlin 35(II), 373-381.

HACQUEBARD, P.A. 1997. Contributions of palynology to Carboniferous biostratigraphy and coal geology of the Atlantic provinces of Canada. Review of Palaeobotany and Palynology 95, 7-29. DO] 10.1016/S0034-6667(96)00025-5

HACQUEBARD, P.A. \& CAMERON, A.R. 1989. Distribution and coalification patterns in Canadian bituminous and anthracite coals. International Journal of Coal Geology 13, 207-260.

DOI 10.1016/0166-5162(89)90095-5

KRINGS, M. \& KERP, J.H.F. 1997. An improved method for obtaining large pteridosperm cuticles. Review of Palaeobotany and Palynology 96, 453-456.

DOI 10.1016/S0034-6667(96)00059-0

KRAUSKOPF, K.B. 1967. Introduction to Geochemistry. 617 pp. McGraw-Hill Book Co., New York.

LIN, R. \& RITZ, G.P. 1993. Reflectance FT-IR microspectroscopy of fossil algae contained in organic-rich shales. Applied Spectroscopy 47, 265-271. DO1 10.1366/0003702934066794

LOCKHEART, M.J., VAN BERGEN, P.F. \& EVERSHED, R.P. 2000. Chemotaxonomic classification of fossil leaves from the Miocene Clarkia lake deposit, Idaho, USA based on $n$-alkyl lipid distribution and principal component analyses. Organic Geochemistry 31, 1223-1246.

DO1 10.1016/S0146-6380(00)00107-8

LOOY, C.V. 2007. Extending the range of derived Late Paleozoic conifers: Lebowskia gen. nov. (Majonicaceae). International Journal of Plant Sciences 168(6), 957-972. DOI 10.1086/518256

Lyons, P.C., OREM, W.H., MASTAlerZ, M., ZODROW, E.L., VIETH-REDEMANN, A. \& BUSTIN, M. 1995. ${ }^{13} \mathrm{C}$ NMR, micro-FTIR and fluorescence spectra, and pyrolysis-gas chromatograms of coalified foliage of late Carboniferous medullosan seed ferns, Nova Scotia, Canada: Implications for coalification and chemotaxonomy. International Journal of Coal Geology 27, 227-248. DOI 10.1016/0166-5162(94)00024-T

MÄGdefraU, K. 1956. Paläobiologie der Pflanzen. $3^{\text {rd }}$ Auflage. 443 pp. VEB Gustav Fischer Verlag, Jena.

McKinney, D.E., Bortriatynski, J.M., CARson, J.W., De LEEUW, J.W. \& ATCHER, P.G. 1996. Tetrathymethylammonium hydroxide (TMAH) thermochemolysis of the aliphatic biopolymer cutan: insights in the chemical structure. Organic Geochemistry 24, 641-650.

DO] 10.1016/0146-6380(96)00055-1

NEAVEL, R.C. \& GUENNEL, G.K. 1960. Indiana paper coal: composition and deposition. Journal of Sedimentary Petrology 30, 241-248.

NeAVEL, R.C. \& MiLler, L.V. 1960. Properties of cutinite. Fuel 39(3), 217-222.

Novoselov, N.P., SAShina, E.S., KuZ'MinA, O.G. \& TroshenkovA, S.V. 2007. Ionic liquids and their use for the dissolution of natural polymers. Russian Journal of General Chemistry 77(8), 1395-1405.

\section{DO] $10.1134 / \mathrm{S} 1070363207080178$}

PALACHE, C., BERMAN, H. \& FRONDEL, C. 1957. The system of mineralogy. Vol. II, $7^{\text {th }} e d .1124$ pp. John Wiley \& Sons, Inc., New York.

PRADIER, B., LANDAIS, P., RoCHDI, A. \& DAVIS, A. 1992. Chemical basis of fluorescence alteration of crude oil and kerogen: 2 . Fluorescence and infrared micro-spectrometric analysis of vitrinite and liptinide. Organic Geochemistry 18, 241-249. DO1 10.1016/0146-6380(92)90065-6

PŠENIČKA, J. 2005. Taxonomy of Pennsylvanian-Permian ferns from coal basins in the Czech Republic and Canada. Partially published $\mathrm{PhD}$ thesis, Charles University, Prague. 
ReICHEL, W. \& Schauer, M. 2006. Das Döhlener Becken bei Dresden: Geologie und Bergbau. Bergbau in Sachsen, Band 12, Sächsisches Landesamt für Umwelt und Geologie, 28-42.

REIHMAN, M. \& SCHABILION, J.T. 1976. Two species of Alethopteris from Iowa coal balls. Proceedings Iowa Academy of Sciences 83, 10-19.

RoSELT, G. 1956. Eine neue Gymnospermenfruktification aus dem Unteren Keuper von Thüringen und ihre Beziehungen zu anderen Gymnospermen. Wissenschaftliche Zeitung Universität Jena, mathematisch-naturwissenschaftliche Reihe 5(1/2), 75-119.

SCHOPF, J.M. 1975. Modes of fossil preservation. Review of Palaeobotany and Palynology 20, 27-53.

DOI 10.1016/0034-6667(75)90005-6

SCHUlZE, F. 1855. Bemerkungen über das Vorkommen wohlerhaltener Cellulose in Braunkohle und Steinkohle. Bericht Verhandlungen königlich-preusischen Akademie der Wissenschaften, Berlin, 676-678.

Sobkowiak, M. \& PAINTER, P. 1992. Determination of the aliphatic and aromatic $\mathrm{CH}$ contents of coals by FT-i.r.: studies of coal extracts. Fuel 71, 1105-1125.

DOI 10.1016/0016-2361(92)90092-3

STACH, E. 1982. Coal petrology. Revised $3^{\text {rd }}$ edition. 535 pp. Gebrüder Borntraeger, Berlin.

Traverse, A. 1988. Paleopalynology. 600 pp. Unwin Hyman, Boston.

TAYlor, G.H., TeIChMÜLler, M., DAVIS, A., DIESEl, C.F.K., LITTKE, R. \& ROBERT, P. 1998. Organic petrology. 704 pp. Gebrüder Borntraeger, Berlin.

TAYLOR, T.N. \& TAYLOR, E.L. 1993. The biology and evolution of fossil plants. 982 pp. Prentice Hall, Englewood Cliffs, New Jersey.

UNGER, F. 1852. Iconographia plantarum fossilium. Denkschrift der kaiserlichen Akadmie der Wissenschaften, mathematischnaturwissenschaftliche Classe, Wien 4, 73-118.

VAN BERGEN, P.F., BLOKKER, P., COLLINSON, M.E., SINNINGHE DAMSTÉ, J.S. \& DE LEEUW, J.W. 2004. Structural miomacromolecules in plants: what can be learnt from the fossil record?, 134-154. In HEMSLEY, A. \& POOLE, I. (eds) The evolution of plant physiology. Elsevier Academic Press, Oxford.

VAn Denbroucke, M. \& LARGEAU, C. 2007. Kerogen origin, evolution and structure. Organic Geochemistry 38(5), 719-833. DO] 10.1016/j.orggeochem.2007.01.001

WAGNER, R.H., VILlEGAS, F. \& FonOlla, F. 1969. Description of the Lower Cantabrian stratotype near Tejerina (León, NW Spain). Comptes Rendu, 6e Congrès Carbonifère, Sheffield 1967(1), 115-138.

Walton, T.J. 1990. Waxes, cutin and suberin. Methods in Plant Biochemistry 4, 105-158.

ZEILLER, M.R. 1882. Observations sur quelques cuticles fossiles. Annales Sciences Natureles 6(13), 217-239.

ZODROW, E.L. 1980. Hydrated sulfates from Sydney Coalfield, Cape Breton Island, N.S. Canada: the copiapite group. The American Mineralogist 65, 961-967.

ZODROW, E.L. 1983. Some geochemical aspects of sedimentary rocks in proximity of coals, Sydney Coalfield (Upper Carboniferous), Cape Breton Island, Nova Scotia, Canada. International Journal of Coal Geology 2, 299-320. DOI $10.1016 / 0166-5162(83) 90015-0$
ZODROW, E.L. 1985. Odontopteris Brongniart in the Upper Carboniferous of Canada. Palaeontographica, Abteilung B 196, 79-110.

ZODROW, E.L. 2005. Colliery and surface hazards through coal-pyrite oxidation (Pennsylvanian Sydney Coalfield, Nova Scotia, Canada). International Journal of Coal Geology 64, 145-155. DOI 10.1016/j.coal.2005.03.013

ZODROW, E.L. \& ClEAL, C.J. 1985. Phyto- and chronostratigraphical correlations between the late Pennsylvanian Morien Group (Sydney, Nova Scotia) and the Silesian Pennant Measures (south Wales). Canadian Journal of Earth Sciences 22(10), 1465-1473. DOI 10.1139/e85-152

ZODROW, E.L. \& CLEAL, C.J. 1993. The epidermal structure of the Carboniferous gymnosperm frond Reticulopteris. Palaeontology 36(1), 65-79.

ZODROW, E.L. \& CLEAL, C.J. 1998. Revision of the pteridosperm foliage Alethopteris and Lonchopteridium (Upper Carboniferous), Sydney Coalfield, Nova Scotia, Canada. Palaeontographica, Abteilung B 247, 65-122.

ZODROW, E.L. \& MASTALERZ, M. 2001. Chemotaxonomy for naturally macerated tree-fern cuticles (Medullosales and Marattiales), Carboniferous Sydney and Mabou Sub-Basins, Nova Scotia, Canada. International Journal of Coal Geology 47, 255-275. DOl 10.1016/S0166-5162(01)00045-3

ZODROW, E.L. \& MASTALERZ, M. 2002. FTIR and py-GC-MS spectra of true-fern and seed-fern sphenopterids (Sydney Coalfield, Nova Scotia, Canada, Pennsylvanian). International Journal of Coal Geology 51, 111-127.

DOI 10.1016/S0166-5162(02)00086-1

ZODROW, E.L. \& MASTALERZ, M. 2007. Functional groups in a single pteridosperm species: Variability and circumscription (Pennsylvanian, Nova Scotia, Canada). International Journal of Coal Geology 70, 313-324.

DOI 10.1016/j.coal.2006.06.010

ZODROW, E.L. \& MCCANDLISH, K. 1978. Roof weakness: fossilization and (cyclic) regenerative hydrated sulphates. Canadian Institute of Mining and Metallurgy Bulletin 71(796), 90-91.

ZODROW, E.L., PŠENIČKA, J. \& BEK, J. 2005. A reassessment of the taxonomy of Oligocarpia bellii (Late Pennsylvanian, Sydney Coalfield, Nova Scotia, Canada). Palaeontographica, Abteilung B 272, 51-65.

ZODROW, E.L. \& VASEY, G.M. 1986. Mabou Mines Section: biostratigraphy and correlation (Pennsylvanian Pictou Group, Nova Scotia, Canada). Journal of Paleontology 60(2), 208-232.

Zodrow, E.L., Wiltshire, J. \& MCCANDlish, K. 1979. Hydrated sulfates in the Sydney Coalfield of Cape Breton, Nova Scotia: II Pyrite and its alteration products. Canadian Mineralogist 17, 63-70.

Zodrow, E.L., Tenchov, Y.G. \& Cleal, C.J. 2007. The Linopteris obliqua plant (Medullosales, Pennsylvanian). Bulletin of Geosciences 82(1), 51-84.

DO] 10.3140/bull.geosci.2007.01.51

Zodrow, E.L., MastalerZ, M., OREM, W.H., ŠIMU゚NeK, Z. \& BASHFORTH, A.R. 2000. Functional groups and elemental analyses of cuticular morphotypes of Cordaites principalis (Germar) Geinitz, Carboniferous Maritimes Basin, Canada. International Journal of Coal Geology 45, 1-19. DO] 10.1016/S0166-5162(00)00018-5 